TEME, г. XLIII, бр. 2, април - јун 2019, стр. 295-308

\begin{tabular}{lr}
\hline \hline Оригинални научни рад & https://doi.org/10.22190/TEME171114020B \\
Примљено: 14.11.2017 & UDK 316.774:004.738.5(497.6)
\end{tabular}

Ревидирана верзија: 5. 1. 2019.

Одобрено за штампу: 5. 3. 2019.

\title{
NEWS CYCLE IN ONLINE MEDIA: NETWORKED WORLDS OF PAST AND FUTURE
}

\author{
Vedada Baraković*, Mirza Mahmutović \\ University of Tuzla, Faculty of Philosophy, Tuzla, Bosnia and Herzegovina \\ vedada.barakovic@untz.ba
}

\begin{abstract}
This paper investigates the specific models and patterns of production, dissemination and dynamics of news in the Bosnia and Herzegovina online sphere, as well as the mechanisms which prolong or reduce news cycles. The research assumption is that the news network is created and maintained under the influence of the specifics of journalism, as well as based on the interest of the audience for a particular topic and under the influence of the mainstream influencers who, within the context of political influence, the dominant ideologies and participatory cultures determine the news cycles and create the prevailing discourse. This research was carried out based on the media coverage of the topics related to the recent war history (revision of the verdict by the Hague Tribunal on Bosnia and Herzegovina's lawsuit against Serbia), and on the topics related to the future of Bosnia and Herzegovina (coordination mechanism in the process of Euro-Atlantic integration), all in order to prove that the topics related to the past have an extended lifecycle and a stronger impact on the audience.
\end{abstract}

Key words: Bosnia and Herzegovina, news cycle, past, future, discourse.

\section{ЦИКЛУС ВЕСТИ У ОНЛАЈН МЕДИЈИМА: УМРЕЖЕНИ СВЕТОВИ ПРОШЛОСТИ И БУДУЋНОСТИ}

\footnotetext{
Апстракт

У овом раду истражују се специфични модели и обрасци продукције, дисеминације и динамике посредовања вести у босанско-херцеговачкој онлајн сфери, те механизми који продужавају или редукују циклусе вести. Претпоставка истраживања је да ce news network конституише и (п)одржава под утицајем специфичности поља новинарства, интереса публике за одређену тему, те под утицајем тзв. мејнстрим инфлуенсера, који, унутар спреге политичког утицаја, доминатних идеологија и партиципаторских култура, детерминишу циклусе вести и креирају преовлађујући дискурс. Истраживање је рађено на студији случаја медијског праћења тема везаних за скорашњу ратну прошлост (ревизија пресуде Хашког трибунала по тужби Босне и Херцеговине против
} 
Србије за геноцид) и тема које се тичу будућности Босне и Херцеговине (механизам координације у процесу Евроатлантских интеграција) како би се доказало да теме везане за прошлост имају продужени циклус трајања и снажнији утицај на публику.

Кључне ријечи: Босна и Херцеговина, циклус вести, прошлост, будућност, дискурс.

\section{INTRODUCTION}

The today's modern media environment is often referred to as a hybrid environment, which is a kind of a combination of traditional and digital media, and where it is difficult to recognize and distinguish only one type of media, since both the traditional and new media are based on the digital platforms and hybrid types of production and distribution of media content. During the pre-Internet age, the production and distribution of media content was based on regulated conventions, recognizable structures and processes that ultimately resulted in a stable product which, from the aspect of study and analysis, was a constant that could be investigated at any given time provided the accessibility to the content. That is, the content published in the newspapers, on the radio or on television could not be changed without being treated as a completely new content or a correction of the previously published content. However, the new media environment provided an entirely new approach to the production (and distribution) of content. A particularly important feature of digital production is the (hyper)dynamics of the change (of the elements) within the same media content over a very short period of time (with the tendency towards the immediate moment) so that, if the content is not saved and stored at the very moment it appears, any subsequent change can produce (and it truly produces) new content and new meaning. In science, this routine of production and distribution of news is called the continuous news cycle (Deuze, 2003).

Continuous news cycle is a term that has recently started being used when investigating news production in a digital environment; however, media production has always been taking place in specific cycles that have depended on the type of media, the type of topic and the type of audience. In a traditional environment, this meant recognizing standard practices and routines of production, dissemination and reception of media content. However, the continuous news cycle implies a higher level of understanding of the routine of media production, both in the context of the individual content cycle, and in the context of the overall design of the online sphere. Production and dissemination of online content is nowadays based on the collaborative processes involving many aspects, which in various ways influence the agenda-setting and framing of news, the selection (gatekeeping) of the topics, as well as the length of the 
individual content. The selection (and distribution) of news nowadays is no longer a privilege of large organizations, nor is the production of news a one-way process. This means that the audience can also participate in the process of news gatekeeping and framing (Shoemaker \& Vos, 2009, p.7), and influence the agenda of the media and the agenda of the audience, that is, in the circular process of the creation of the agenda, the audience can channel the appropriate discourses. Participatory culture of the online content production has nowadays opened up a number of research challenges, starting from questioning what kind of news attracts public attention, and what is the level of audience participation in the final design of news: comments, sentiments, etc. (Domingo, 2008). Do these collaborative processes change and in what way? (Manovich, 2001, p.6 ) Who are the key news gatekeepers? (Shoemaker\&Vos, 2009, p.135). Who are the key players in digital news? What type of topic affects the length of the news cycle? Which online channels do most often appear as the key influencers in the digital public sphere? How do the specific socio-cultural environment and journalism affect the abovementioned processes?

This paper contributes to the research of the aforementioned processes in the context of the Bosnia and Herzegovina's public sphere. This paper focuses on the research of the dynamics and processes of production and dissemination of online content with the focus on identifying the topics that provide a longer news cycle and the involvement of a larger number of participants. Furthermore, this paper also tends to identify the key participants and influencers who influence the selection, framing and agenda-setting of individual topics. The case study is based on the analysis of events related to the recent (traumatic) past (revision of the verdict of the Hague Tribunal on Bosnia and Herzegovina's lawsuit against Serbia for genocide) and the events concerning the future of the Bosnia and Herzegovina community (coordination mechanism between the different levels of government in the process of the EU integration). The research assumption of this paper is that the news cycle related to the recent past in the Bosnia and Herzegovina online media lasts significantly longer and includes (a significantly) greater number of participants and more distribution channels than in the case of topics focused on the future of the Bosnia and Herzegovina community, while the dominant influencers affect the creation of the audience discourse.

\section{LITERATURE REVIEW}

News in the new media environment can be said to be nonpermanent, continuous, collaborative, multimodal and interconnected processes of content production which are based on the journalistic principles that, theoretically, can last indefinitely. These processes are radically different from the news production in an analogous environment 
in which traditional media were created and developed, and in which the standards and matrices of journalistic reporting that depend on prior planning and predictability were established. Thus, journalism in the new media environment is characterized by participation, convergence, speed, multimedia, and hyperlinks (Domingo, 2008). These characteristics imply a different way to research these media, so theoreticians suggest that digital news should be approached as a process rather than a product. During the production process, news is a dynamic category that appears in different versions. This feature is crucial when identifying the production cycle of online news, from the mimicry process of replicating the traditional production cycles typical for the pre-digital era. In addition to the interaction, momentariness, multimedia and hyperlinks, news in the online environment also take on a specific feature called liquidity, that is, the ability of news to get distributed very quickly through different channels, with the pronounced dynamics of these processes (Deuze, 2003; Domingo, 2008; Bozckowski \& Martin, 2007). The liquid character of news in the new media environment means, among other things, that news is constructed, reconstructed, and recycled with an (un)predictable dynamics, within the (un)recognizable frameworks dictated by the (in)visible creators of the agenda, and in doing so, the individual content becomes (hyper)dynamic which means that the changes can occur (and they do occur) at such a speed which is difficult to observe, map and store. Such features imply a change of the traditional, predictable, repetitive news cycle to the so-called continuous news cycle (Deuze, 2003).

The online sphere is nowadays dominated by the continuous news cycle, and this new media type of news production is also called the 24/7 news cycle (Turnbull, 2012). The continuous (24/7) news cycle has influenced the media, journalism and the audience in such a way that today the scientists are searching for the new models and concepts that will explain how and with what intensity the public communication sphere is changing, and how and with what intensity the media, journalism, the public and the society as a whole are being transformed. For example, nowadays, the news itself is transformed from what has happened to what is happening, and the news is claimed to be continuous negotiation, ambient goods in participatory media culture, which is at the same time both intensively discursive and discursively intense, while the decision on what is news is determined by the audiences (Hermida, 2010). The journalist is now no longer an exclusive producer, nor is the institutionbased media of mass communication the exclusive information disseminator. Now the content users participate in the information production process, and they have a dual role: they are both consumers and content producers (so called prosumers), and regardless of whether they share the information or comment on it, they participate in content creation. In this way, the information duration cycle in the digital environment has an unpredictable 
flow and duration that is determined by numerous factors, which is the subject of research of recent studies worldwide. One of the most important factors is definitely the interest of the audiences and how they keep track of the digital media content. Boczkowski and Martin (2007) noticed a disproportion between the preferences of journalists and news consumers (audiences), especially online media consumers. Surveys (Anderson, 2011; Tandoc, 2014) have shown that a number of editorial decisions in online media are based on the statistical data of the effects that not only the type of topic, but also the way of processing that topic will have. The topic is chosen and processed based on how much attention it will attract; however, nowadays, that does not only apply to tabloid topics, but to other topics as well, because the click actually shows whether the news has reached the audiences and what effect it had. (Karlsson, 2012). The usual routine for monitoring the content of digital media is carried out within the so-called half-life cycle, which is actually the average time the audience stays interested in a particular topic (Castillo, El-Haddad, Pfefer, 2014). Another important factor is the type of content. Various surveys (Castillo, El-Hadda, Pfeffer, 2014; Boczkowski, 2009) have shown that political, sports, entertainment and celebrity topics last longer than the economics topics. The way the content is shared also affects the length of the news cycle as well as the degree of featurization of the topic.

\section{METHODOLOGY}

In recent years, the research methodology of online media content has expanded in several directions, while the researchers are facing many difficulties and challenges. The first type of difficulty relates to a constant change of content that would require local recording and storage of content in real time using some downloading software or screen copier tools. Some surveys were based on the monitoring of a website content, and every day, every three hours the content related to a topic was downloaded (Hutchinson, 2016), which did not guarantee that in the meantime there were no quantitative and/or qualitative changes in the individual text and in the overall research corpus (Carllos, El-Haddad, Pfeffer \& Stempeck, 2014). News in the online environment are also treated as blueprints (Deuze, 2003) that are subject to various types of adjustments, some of the particularly significant ones being the links to other news, topics, media, etc. By recognizing this kind of problem, Shoemaker \& Rees (1996, p.12) noted that determining the research analysis metric is one of the most important starting points in researching and analysing online media content. In the case of online research, the published text or parts of the published text (title, heading and sub-heading) must be the analysis metric, but, as already mentioned, since online news is viewed as a process, it is also necessary to identify the cycle in which the news is measured. Karlsson 
(2012), for example, proposes that news should be checked every 10 minutes for 3 hours a day using the WinHTTrack tool, a screen copier that selects the content from the homepage of the websites that are presumed to contain the most important news. There were also numerous other attempts to establish methodological framework for online content research, while in this paper, the data collection for the research was done using the Mediatoolkit application ${ }^{1}$, as well as the digital tools Google Lipmannian, Google Image Scraper, and Topsy.com. Using these tools, the following variables were measured: 1) The type of media in which the content appeared: websites and social networks (Source); 2) Content linked to the research topic: texts/posts/comments (Mention); 3) Estimated number of people who could view the content (Reach); 4) Interaction with the audience: number of likes, shares and comments on social media (Interaction); 5) Estimate of the success of the text compared to other texts on the same website (Virality) ${ }^{2}$; and, 6) the attitude of the content author (Sentiment).

For the analysis purposes, media contents that covered the events related to the recent traumatic past of Bosnia and Herzegovina (revision of verdict) and the events related to the future of Bosnia and Herzegovina (designated as coordination mechanism) were chosen.

Revision of verdict refers to the revision of the Hague Tribunal's verdict from 1993 following the lawsuit of Bosnia and Herzegovina against the Federal Republic of Yugoslavia (at that time comprising of Serbia and Montenegro) for violating The Convention on the Prevention and Punishment of the Crime of Genocide. After this complaint from $26^{\text {th }}$ February 2007, the International Court of Justice (ICJ) in The Hague reached the verdict declaring Serbia not to be directly responsible for those crimes and not being obliged to reimburse Bosnia and Herzegovina, but Serbia was to be held responsible for not having prevented those crimes and for not having punished the perpetrators of the crime. According to the ICJ legal acts, this verdict was final, which means that there was no possibility to lodge an appeal, but still a revision could be initiated within 10 years from the day of the original verdict if new evidence was obtained that was not known when the verdict was reached. But, Sakib Softic, who was the legal representative during the first dispute,

\footnotetext{
${ }^{1}$ Real time online press clipping tool that can search for more than a million news https://www.vecernji.hr/techsci/mediatoolkit-postao-prvi-domaci-alat-za-real-timeonline-press-clipping-938409www.vecernji.hr

${ }^{2}$ The concept of virality refers to the liquidity/fluidity of content in the online environment. For example, if a certain page has 10,000 interactions (likes/shares/tweets) within the first 10 minutes after the release, while some other text has 1,000 interactions on social media, then the first text is 10 times more viral. Virality $0 \mathrm{x}$ means that the text had no interaction, $0.1 \mathrm{x}$ means that a text is 10 times less viral than the average interaction of other texts; $1 \mathrm{x}$ means that the text has the same level of interaction as the average interaction, while everything over 1 indicates that many times more than the average.
} 
submitted a motion for revision, and who, according to the Bosnia member of the Presidency had the authorization which was valid since the 2007 process.

Regardless of the legitimacy of the legal representative and the verification of the validity of the body that approved the legal representation, there is information that in May 2016, the members of the Bosnia and Herzegovina Presidency and the ICJ talked about the request for revision, as well as about the status of the legal representative of Bosnia and Herzegovina, which indicates that the outcome of this legal proceeding was practically announced at that point. There was no doubt that both the lawsuit and the revision of verdict were a legal matter of international relations between Bosnia and Herzegovina and Serbia, and it was expected that this event would cause media attention and public attention which actually happened ${ }^{3}$ (un)expectedly, with significantly more media coverage in the Republic of Srpska than in the Republic of Serbia.

The second corpus of data designated as coordination mechanism relates to the functioning of the coordination mechanism of bodies and institutions participating in various activities related to the process of joining the European Union. In 2016, the Council of Ministers of Bosnia and Herzegovina formed 33 working groups for European integration. Representatives of relevant institutions from all levels of government were involved in these working groups in accordance with their respective jurisdictions. The coordination mechanism is complex and it has proven to be very difficult for the Bosnia and Herzegovina institutions to work together. For example, the working group for the Right of establishment and freedom to provide services consists of as many as 102 institutions from all government levels in Bosnia and Herzegovina. Decision-making in all systems of jurisdiction, including working groups, is done with a consensus. ${ }^{4}$ Since the adoption of the coordination mechanism, this mechanism has not worked and no significant improvement has been made $^{5}$. A functional coordination mechanism should, in practice, enable the consensus to be reached, since that is the main prerequisite to accept the application of Bosnia and Herzegovina for EU membership, and it is an essential process that will determine the EU integration and the future of Bosnia and Herzegovina.

\footnotetext{
${ }^{3}$ Google offers more than 400,000 results for the key words: Verdict Bosnia and Herzegovina Serbia

${ }^{4}$ https://www.klix.ba/vijesti/bih/mehanizam-ne-koordinacije-bez-saglasnosti-100institucija-nema-usvajanja-odluka/170518071 (visited on 15/7/2017)

${ }^{5} \mathrm{http} / / / \mathrm{cps} . \mathrm{ba} / \mathrm{mehanizmi-koordinacije-u-eu-integraciji-bih/}$
} 


\section{RESULTS AND INTERPRETATION}

The analysis in this paper covered a period when no significant events related to the subject of research were recorded (between March $10^{\text {th }}$ and April $\left.10^{\text {th }}, 2017\right)$. The analysis metrics were content posted on website, post on Facebook, tweet on Twitter and video on YouTube. During the research period, the topics related to the revision of the verdict were given much more attention in the selected media than the topics linked to the coordination mechanism. While a total of $\mathrm{N}=885$ contents related to the revision of the verdict were published, the number of contents related to the coordination mechanism was nearly seven times less $(\mathrm{N}=$ 139). The majority of content related to both topics was published on the websites, while the frequency of content on social media was somewhat different. Comparative overview of the frequency and ratio between the individual analysis metrics is shown in Table 1.

Table 1. Frequency and ratio between the analysed contents

\begin{tabular}{lcccc}
\hline & \multicolumn{2}{c}{ Verdict revision } & \multicolumn{2}{c}{ Coordination mechanism } \\
\cline { 2 - 5 } & Frequency & Percentage & Frequency & $\begin{array}{c}\text { Percentage } \\
\%\end{array}$ \\
\hline Web & $\mathrm{N}$ & $\%$ & $\mathrm{~N}$ & $\%$ \\
Facebook & 704 & $81 \%$ & 115 & $83 \%$ \\
Twitter & 66 & $7 \%$ & 12 & $8 \%$ \\
YouTube & 58 & $5.5 \%$ & 8 & $6 \%$ \\
\hline Total & 57 & $6.5 \%$ & 4 & $3 \%$ \\
\hline
\end{tabular}

Verdict Revision

The most articles related to the verdict revision were published on the website www.klix.ba ( $\mathrm{N}=147$ mentions). From the aspect of the number of visitors who could see the content, the most prominent website was http://balkans.aljazeera.net/,while the most significant influencer on Twitter was the portal blic.rs. Table 2 shows the three most important influencers on the websites, Facebook and Twitter.

Table 2. Top influencers by average reach

\begin{tabular}{lll}
\hline Web (Reach) & Twitter (Reach) & Facebook (Reach) \\
\hline aljazeera.net (21524) & @blic.rs (21398) & AlJazeeraBalkans (64611) \\
voanews.com (18841) & @ AJBalkans (9107) & Dnevni avaz (37290 \\
Dnevnizurnal.com (9836) & @ KratkeVijesti (7667) & Fokus.ba (24883) \\
\hline
\end{tabular}

An overview of the top three influencers with the highest degree of interaction: likes, shares, and tweets is shown in Table 3. 
Table 3. Top influencers by average interaction

\begin{tabular}{lll}
\hline Web (interactions) & Twitter (interactions) & Facebook (interactions) \\
\hline dnevnizurnal.com (6246) & @ Ridjobrki (62) & AljazeeraBalkans (899) \\
Balkanekspres.com (1126) & @ SrkiPuhalo (16) & Žurnal magazin (286) \\
Zurnal.info (698) & @Blic_online (8) & Moja Hercegovina (266) \\
\hline
\end{tabular}

The most significant share of the content (virality) of the research topic compared to other topics published during the same period of time was noticed on the following web pages: rts.tv (15.68); vijesti.ba (10.71) bljesak.info (7.06). There was no significant deviation observed on social networks.

The views of the participants ${ }^{6}$ in the discussions about this topic were mostly negative $\mathrm{N}=700(80 \%)$, there was significantly less of those who were neutral, $\mathrm{N}=123$ (14\%), while there was the least positive opinions on the topic, $\mathrm{N}=53(6 \%)$.

Regarding the verdict revision topic, the content distribution process was extremely dynamic, which means that around 30 news related to the research topic were published online daily. There was no particularly significant individual event that was the dominant one in the news, since most of the content included the reactions of governmental and nongovernmental organizations as well as the individuals to the Hague tribunal's verdict. Although the research did not include the analysis of the process, the dynamics and sentiment on the forums, it is important to mention that, for example, the intensity of the content on the forum of the portal klix.ba was such that the forum initiated for the subject of the Revision of the Verdict against Serbia had as many as 7899 posts, with an average of 30 different news published a day.

\section{Coordination Mechanism}

The news that was related to the coordination mechanism in the analysed period was significantly less present than those related to the verdict revision. The news on coordination mechanism were the most frequent on the websites $\mathrm{N}=115(83 \%)$, while they were significantly less frequent on all three analysed social media $\mathrm{N}=24(17 \%)$. The same as in the case of the verdict revision, the news on coordination mechanism topic was mostly published on the portal klix.ba $(\mathrm{N}=18)$. From the aspect of the number of visitors who could see the content, the most influential portal

\footnotetext{
${ }^{6}$ The sentiment was measured using the program Topsy.com, which monitored the authors and other participants in communication related to the defined topic with the highest viral effect. The effect was measured by the number of shares, downloads and expressed emotions (shares, likes, dislikes) and described by a scale from 1 to 100 . It should be noted that this digital tool does not measure the sentiment of individual content.
} 
was http://balkans.aljazeera.net/. Table 4 shows the top three influencers on the websites, Facebook and Twitter.

Table 4. Top influencers by average reach

\begin{tabular}{lll}
\hline Web (Reach) & Twitter (Reach) & Facebook (Reach) \\
\hline blic.rs (6759) & @ KratkeVijesti (7638) & ATVBanjaluka (3600) \\
klix.ba (4528) & @ RomaAJB (136) & TrebinjeDanas.com (600) \\
aa.com.tr (1244) & $@$ dnevnimostar (67) & Klix.ba (400) \\
\hline
\end{tabular}

An overview of the top three influencers with the highest degree of interaction: likes, shares, and tweets is shown in Table 5.

Table 5. Top influencers by average interaction

\begin{tabular}{lll}
\hline Web (interactions) & Twitter (interactions) & Facebook (interactions) \\
\hline depo.ba (173) & @ RomaAJB (2) & ATVBanjaluka (39) \\
Atvbl.com (151) & @U_Vukic (1) & TrebinjeDanas.com (11) \\
Sdp.ba (698) & @ KratkeVijesti (1) & Klix.ba (3) \\
\hline
\end{tabular}

Within the category Top influencers by average virality there was no significant deviation from other texts, while the values for all analysed media were 0 , which means that this topic did not trigger more attention than other topics published during the research period.

The views of the participants in the discussions about this topic were mostly neutral $\mathrm{N}=57(41 \%)$, there was somewhat less of those who were positive, $\mathrm{N}=123(14 \%)$, while there was the least of negative opinions on the topic, $\mathrm{N}=53(6 \%)$.

In the case of the coordination mechanism, a specific article that had more pronounced dynamics compared to other topics was observed in the text called Coordination Mechanism at Work published on klix.ba on $14 / 3 / 2017$, at $21: 31$, which was not signed by the author. ${ }^{7}$ It was getting shared during 12 hours and it was copied by 11 websites, while the publishing dynamics was approximately one publication an hour.

The previous analysis confirmed the initial research assumption that the topics related to the recent Bosnian traumatic past trigger a much bigger interest in the online sphere, and that the cycle of such news lasts much longer than of those related to the future of Bosnia and Herzegovina. Although the research was of limited duration (lasted for a month), and although it included the monitoring of only two (significant) topics, it emphasized some of the key features of the Bosnia and Herzegovina media sphere and the specifics of journalism. The transformation of journalism in Bosnia and Herzegovina after the end of the war that lasted from 1992 to

\footnotetext{
${ }^{7}$ In the case of unsigned texts, it can be assumed that they are PR products.
} 
1995 and the transition from the socialist model started in a media system that generally corresponded to a mediterranean, polarized plural model dominated by ethnocentrism and the promotion of (ethnic) values that journalists considered obliged to defend, and they tended to accept and reproduce the interpretative frameworks of ethnic and nationalist ideologies (Džihana, 2011). Even though 20 years have passed after the war in Bosnia and Herzegovina, ethnic and nationalist ideologies permeate the entire public sphere, so the public discourse in Bosnia and Herzegovina is strongly influenced by the past, which is used as a symbolic capital in the pursuit and preservation of power. The recent traumatic past is the subject of everyday (re)interpretation, construction and reconstruction, primarily in the political discourse, but it is also very dominant in the media discourse as well, since the media sphere in Bosnia and Herzegovina is ethnically and nationalistically polarized. Media in Bosnia and Herzegovina are directly or indirectly influenced by ethnic and nationalist politics (Ćurak, 2009), which can also be said for online media as different surveys have shown that traditional media organizations dominate the initial processes of gatekeeping and framing, and that the online media copy and reuse such news in different ways (Baraković, Mahmutović, 2014).

The research done in this paper has shown that the media and the public give considerably more attention to past events, than to the events related to the future of Bosnia and Herzegovina. Thus, during the observed period, the contents related to the revision of the verdict for Serbia genocide against Bosnia and Herzegovina were 6 times more present than the contents that dealt with the coordination mechanism, including all media: websites, social media and forums launched for this topic. The share of the content on this topic was significantly higher compared to other topics published during the same period (virality), meaning that these contents were up to 16 times more viral than other content published within the same time period. On the other hand, the virality of the content related to the verdict revision in the observed period was not recorded for any published content. The individual news cycle was also significantly different in the case of verdict revision than in the case of coordination mechanism. When it comes to the coordination mechanism, the daily news cycle lasted for 12 hours, a total of 20 articles were published, and the news was taken over by 11 portals, while the publication dynamics was around one release per hour. However, the activity was statistically insignificant on social media. In the case of the verdict revision, the daily news cycle lasted for almost 24 hours and the number of registered articles was 148, with the content being predominantly published on social media. The news publishing dynamics was around seven news per hour. What was also interesting was the fact that the top influencers from the aspect of interaction (likes, shares, comments) were the media that had the most visitors, while this was not the case with the coordination mechanism. 
Although the individual effects of the analysed content were difficult to measure, the modern digital tools were used to track the number of views of individual news and other features that are used to measure the success of the news (number of shares, number of comments and sentiments of participants in the discussion on a particular subject). The effect was measured by the number of shares, downloads and emotions expressed (shares, likes, dislikes) using the scale from 1 to 100 . This is how it was observed and measured that the participants in the discussion had extremely negative attitudes when it came to the verdict revision topic (as much as $80 \%$ of the analysed content), while the participants in the discussion were mostly neutral when it came to the coordination mechanism topic (over $40 \%$ of the analysed content). It is important to point out that the positive attitude was the least present - only around $6 \%$ in both cases.

\section{CONCLUSION}

The research done in this paper contributes to the surveys that dealt with information flows in specific social communities such as Bosnia and Herzegovina. Global media system functions as a network that involves many participants, but that the network system of information flow is very stably and significantly supplied by information by the mainstream media that again appear as the information sources for other media as well (Weber \& Monge, 2011). However, the information flow and the lifecycle of a news story depends on many other factors that are related to specific social conditions and contexts, and in particular to the specific fields of journalism that appear in the online sphere as a type of symbiosis of mainstream flows, participatory cultures, and reflections of predominant ideologies within the public communication practices of a particular community. Moreover, these flows are strongly influenced by the mainstream sources/influencers, who, within the context of political influence, dominant ideologies and participatory cultures create a predominant discourse of the (im)possible.

The research done in this paper is complementary to numerous previous studies related to the media relation to Bosnia and Herzegovina social reality (Ćurak, 2009; Šimić, 2016; Baraković \&Mahmutović, 2014). Journalism and the entire public sphere are burdened with the recent traumatic past, which is why we find an obvious example of the dichotomy in the relationship between Bosnia and Herzegovina and the European Union from the aspect of media and from the point of view of the Bosnia and Herzegovina political elite. Furthermore, there is an obvious inability to reach a consensus on the future of the nation. The blurred vision of the future is being replaced by the constant recycling of topics from the past, which are, with the help of modern Internet platforms networked, shared and disseminated with the (un)expected dynamics, sequence, duration and opinions of participants in the discussion. 


\section{REFERENCES}

Anderson, C. (2011). Between creative and quantified audiences: Web metrics and changing patterns of news work in local US newsrooms. Journalism 12(5), $550-566$.

Baraković, V. \& Mahmutović, M. (2014). Bosanskohercegovačka novomedijska ekologija: reciklirajuća neo(o)visnost. [New Media Ecology in Bosnia and Herzegovina: recycling independence] Medijski dijalozi. 19, 205-221.

Boczkowski, P. J., \& Martin, D.S. (2007). When More Media Equals Less News: Patterns of Content Homogenization in Argentina's Leading Print and Online Newspapers. Political Communication 24(2):167-80.

Castido, C., El-Haddad, M., Pfeffer, J.\& Stempeck, M. (2014). Characterizing the Life Cycle of Online News Stories Using Social Media Reactions. CSCW '14 Proceedings of the 17th ACM conference on Computer supported cooperative work \& social computing, pp 211-223. Retrieved on 21 June 2107 from http://chato.cl/papers/castillo_elhaddad_pfeffer_stempeck_2013_news_ lifecycle.pdf

Ćurak, N. (Eds.). (2009). Politička elita u Bosni i Hercegovini i Evropska unija: odnos vrijednosti. [The political elite in Bosnia and Herzegovina and the European Union: the value ratio.] Sarajevo: Institut za društvena istraživanja Fakulteta političkih nauka Univerziteta u Sarajevu.

Deuze, M. (2003). The web and its journalisms: considering the consequences of different types of newsmedia online. New Media \& Society 5(2). Retrieved on 12 July 2107 from https://scholarworks.iu.edu/dspace/bitstream/handle/2022/ 6602/Deuze\%20NMS2003.pdf?sequence=1\&isAllowed=y

Domingo, D. et all (2008). Participatory Journalism Practices in the Media and Beyond, an International Comparative Study of Initiatives in Online Newspapers. Journalism Practice 2(3).

Džihana, A. (2011). Media Intervention and Transformation of the Journalism Model in Bosnia and Herzegovina. Medijska istraživanja. 1-2, 97-118.

Hermida, A. (2010). Twittering the News: The Emergence of Ambient Journalism. Journalism Practice, 4, (3), pp. 297-308. Retrieved on 15 June 2107 from https://papers.ssrn.com/sol3/papers.cfm?abstract_id=1732598\&rec=1\&srcabs $=932681 \&$ alg $=1 \&$ pos $=2$

Hutchinson, D. (2016). An Introduction to Digital Media Research Methods: How to Research and the Implications of New Media Data. Communication Research and Practice, 2(1), ( pp 1-6).

Karlsson, M. (2012). Charting the liquidity of online news: Moving towards a method for content analysis of online news. International Communication Gazette, 74 (4), 385-402.

Manovich, L. (2001). The Language of New Media. London: MIT Press.

Shoemaker, P.J., \& Vos, T.P. (2009).Gatekeeping theory, New York : Routledge.

Shoemaker, P. \& Reese, S. (1996). Mediating the message: theories of influences on mass media content. White Plains, NY: Longman.

Šimić, G. (2016). Uloga istine i medija u post konfliktnom društvu. [The Role of Truth and Media in a Post-Conflict Society] Sarajevo: E-novinar. Retrieved on 2 July 2107 from http://bhnovinari.ba/wp-content/uploads/2012/06/bhn_enovinar-juli2016.pdf

Tandoc, E.C. (2014). Journalism is twerking? How web analytics is changing the process of gatekeeping. New Media \& Society. 16(4): 559-575. 
Turnbull, M. (2011). Politics, Journalism and 24/7 News Cycle. More or Less, Democracy \& New Media. Retrieved on 5 September 2107 from http://www. futureleaders.com.au/book_chapters/pdf/More-or-Less/Malcolm_Turnbull.pdf

Weber, M.S., Monge, P. (2011). The Flow of Digital News in a Network of Sources, Authorities, and Hubs, Journal of Communication 61, 1062-1081.

Welbers, K. (2016). Gatekeeping in the Digital Age. Amsterdam: Vrije Universiteit. Retrieved on 2 September 2107 from https://research.vu.nl/ws/portalfiles/ portal/1587652.

\title{
ЦИКЛУС ВЕСТИ У ОНЛАЈН МЕДИЈИМА: УМРЕЖЕНИ СВЕТОВИ ПРОШЛОСТИ И БУДУЋНОСТИ
}

\author{
Ведада Бараковић, Мирза Махмутовић \\ Универзитет у Тузли, Филозофски факултет, Тузла, Босна и Херцеговина
}

\section{Резиме}

У раду су анализирани специфични механизми који у процесима продукције, дисеминације и динамике посредовања вести у босанско-херцеговачкој онлајн сфери продужавају или редукују циклус вести. Истраживање је рађено на студији случаја медијског праћења тема везаних за скорашњу ратну прошлост (ревизија пресуде Хашког трибунала по тужби Босне и Херцеговине против Србије за геноцид) и тема које се тичу будућности Босне и Херцеговине (механизам координације у процесу Евроатлантских интеграција) како би се доказало да теме везане за прошлост имају продужени циклус трајања и снажнији утицај на публику.

У периоду праћења анализирана је динамика циклуса вести у онлајн медијима, која је показала да се news network у босанско-херцеговачкој онлајн сфери конституише и (п)одржава под утицајем специфичности поља новинарства, те под утицајем интереса публике за одређеном темом, али у значајној мјери и под утицајем тзв. мејнстрим инфлуенсера. Тако се, унутар спреге политичког утицаја, утицаја доминатних идеологија и утицаја партиципаторских култура детерминишу циклуси вести и креирају преовлађујући јавни дискурси. Истраживање у овом раду комплементарно је бројним претходним истраживањама везаним за однос медија спрам босанско-херцеговачке друштвене збиље, која упућују на закључак да је поље новинарства, као и комплетна јавна сфера u БиХ, изразито обремењено скорашњом, трауматичном прошлости.

Поред тога, уочљиво је и настојање наметања дискурса немогућности постизања консензуса о будућности босанско-херцеговачке заједнице, па се замагљена визија будућности замењује сталним рециклирањем тема из прошлости, које се помоћу савремених интернетских платформи умрежавају, деле и дисеминирају (не)очекиваним следом, динамиком и трајањем, а према којима учесници у јавној комуникацији имају различите вредносне ставове. 